Article

\title{
The Genealogy of an Image, or, What Does Literature (Not) Have To Do with the History of Computing? : Tracing the Sources and Reception of Gulliver's "Knowledge Engine"
}

\author{
Johannah Rodgers \\ School of Arts \& Sciences, The City University of New York, 300 Jay St, Brooklyn, NY 11201, USA; \\ JRodgers@CityTech.cuny.edu
}

Received: 25 July 2017; Accepted: 28 October 2017; Published: 8 November 2017

\begin{abstract}
The illustration of the "knowledge engine" included in early editions of Gulliver's Travels is an engraving of a sketch from the notebook of Lemuel Gulliver. In other words, it is a purely fictional object. Yet, Swift's fictional invention and its graphic representations have become part of the documented historical lineage of computing machines. Furthermore, one of Swift's purposes for inventing the "knowledge engine" was to satirize the scientific and technical cultures that now claim it as part of their history. As one piece of the elaborate discursive and material code of Gulliver's Travels, "the knowledge engine," its sources, and its reception offer some unique insights into the relationships that exist amongst factual and fictional narratives, scientific and humanistic discourse, words and images, and print and digital technologies. Although numerous scientific and philosophical texts have been cited as possible sources informing Swift's satirical invention, this article considers a lesser known one, John Peter's 1677 pamphlet Artificial Versifying, or the Schoolboy's Recreation, which is itself a print-based textual machine for generating lines of Latin hexameter verse.
\end{abstract}

Keywords: computational poetics; Jonathan Swift; Gulliver's Travels; history of computing; book history; cultural and media studies; book illustration; history of writing instruction

"I am aware that the statements contained in this Letter may perhaps be viewed as something more than Utopian, and that the philosophers of Laputa may be called up to dispute my claim to originality. Should such be the case, I hope the resemblance will be found to adhere to the nature of the subject rather than to the manner in which it has been treated."

\section{—Charles Babbage (1822, “Letter To Sir Humphry Davy”)}

"In the 'Voyage to Laputa,' there is a description of a machine for the evolving of science automatically. 'By this contrivance, the most ignorant person, at a reasonable charge, and with little bodily labor might write books in philosophy, poetry, politics, law, mathematics, and theology without the least assistance from genius or study."'

—Charles Sanders Peirce (1887, “Logical Machines”)

"In 1726 Jonathan Swift published a description of a wonderful machine, made of equal parts of irony, sarcasm, and mockery, that would automatically write books on all the arts and sciences without the least assistance from genius or study." 
As graphic image, the illustration of what has come to be known as the "knowledge engine" included in early editions of Gulliver's Travels is an engraving of a sketch from the notebook of Lemuel Gulliver (Figure 1). In other words, it is a purely fictional construct. Yet, this fictional invention and its graphic representations have been referenced in scientific and technical articles throughout the 19th and 20th centuries. In fact, so widespread is the notion that the "knowledge engine" is a significant and possibly "originary" source in the history of computing and artificial intelligence that this fiction now has its own Wikipedia page, which documents it as "possibly the earliest known reference to a device in any way resembling a modern computer" (Figure 2). That the Wikipedia page presents the digital image of a print engraving of the "knowledge engine" in such a way as to suggest some association between it and a semiconductor promises only to propel the never ending satire of Gulliver's Travels by further advancing discursive structures connecting the invention to the history of computing devices (Figure 3). Frequently referenced by commentators and critics, who have pointed to the possible connections between it and a range of sources related to the search for a universal or philosophical language, including Raymon Llull and his commentators, John Wilkins, Athanasius Kirchner, and Gottfried Leibniz, the "knowledge engine" was connected by the Swift scholar John Chalker in 1967 to a much lesser known source, John Peter's (1677) pamphlet entitled Artificial Versifying, or the Schoolboy's Recreation ${ }^{1}$ (Figure 4 ).

Travels Into Several Remote Nations by Lemuel Gulliver (Benjamin Motte, 1726)

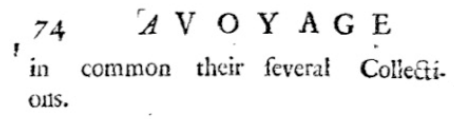

$H_{E}$ alfured me, that this Invention had employed all his Thoughts from his Youth, that he had employed the whole Vocabulary into his Frame, and made the ftricteft Computation of the genera! Proportion there is in the Book between the Numbers of Particles, Nouns, and Verbs, and other Parts of Speech.

I made my humbleft Acknowledgment to this illuftrious Perfon for his great Communicativenefs, and promifed if ever I had the good Fortune to return to my Native Country, that I would do him.Juftice, as the fole Inventer of this wonderful Machine; the Form and Contrivance of which I defired leave to delineate upon Paper as in the Figure here annexed. I told him, although it were the Cuftom of our Learned in Europe to fteal Inventions from each other, who had thereby at

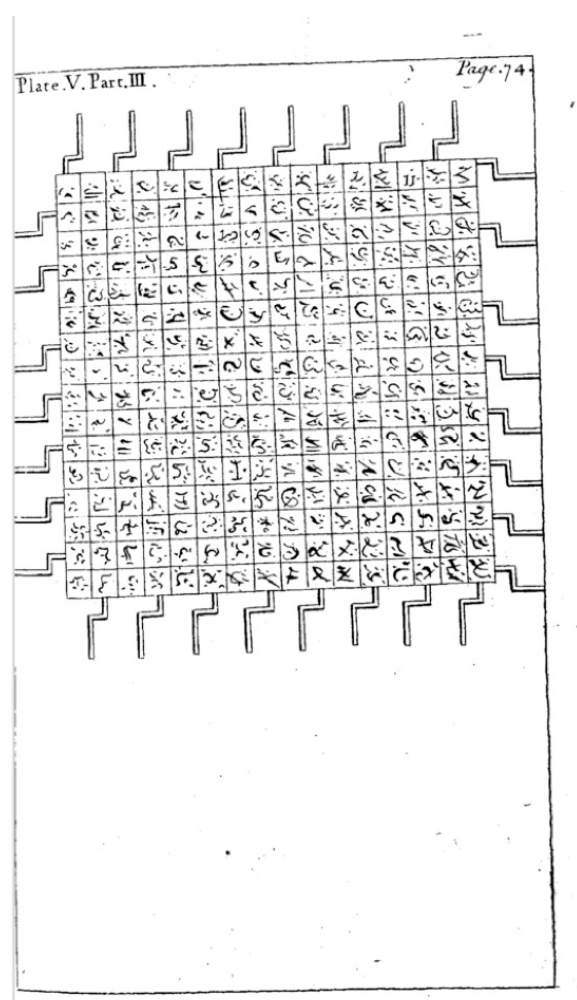

Figure 1. Illustration of "the Engine" from Book 3 of the second edition of Jonathan Swift's Travels Into Several Remote Nations by Lemuel Gulliver (Benjamin Motte, 1726) (Swift 1726).

1 See Scott (1814), Koch (1996), Knowlson (1975), Cornelius (1965), and Swift (1978). For a discussion of the relationships amongst the characters included in the graphic depiction of the "knowledge engine" and their significance in relation to conceptions of China, Chinese writing, the Far East, and the search for "representational legitimacy" in the long 18th century, see David Porter's (1993) discussion in Ideographia (p. 24) and Lydia Liu's (2011) discussion in The Freudian Robot (p. 40). 


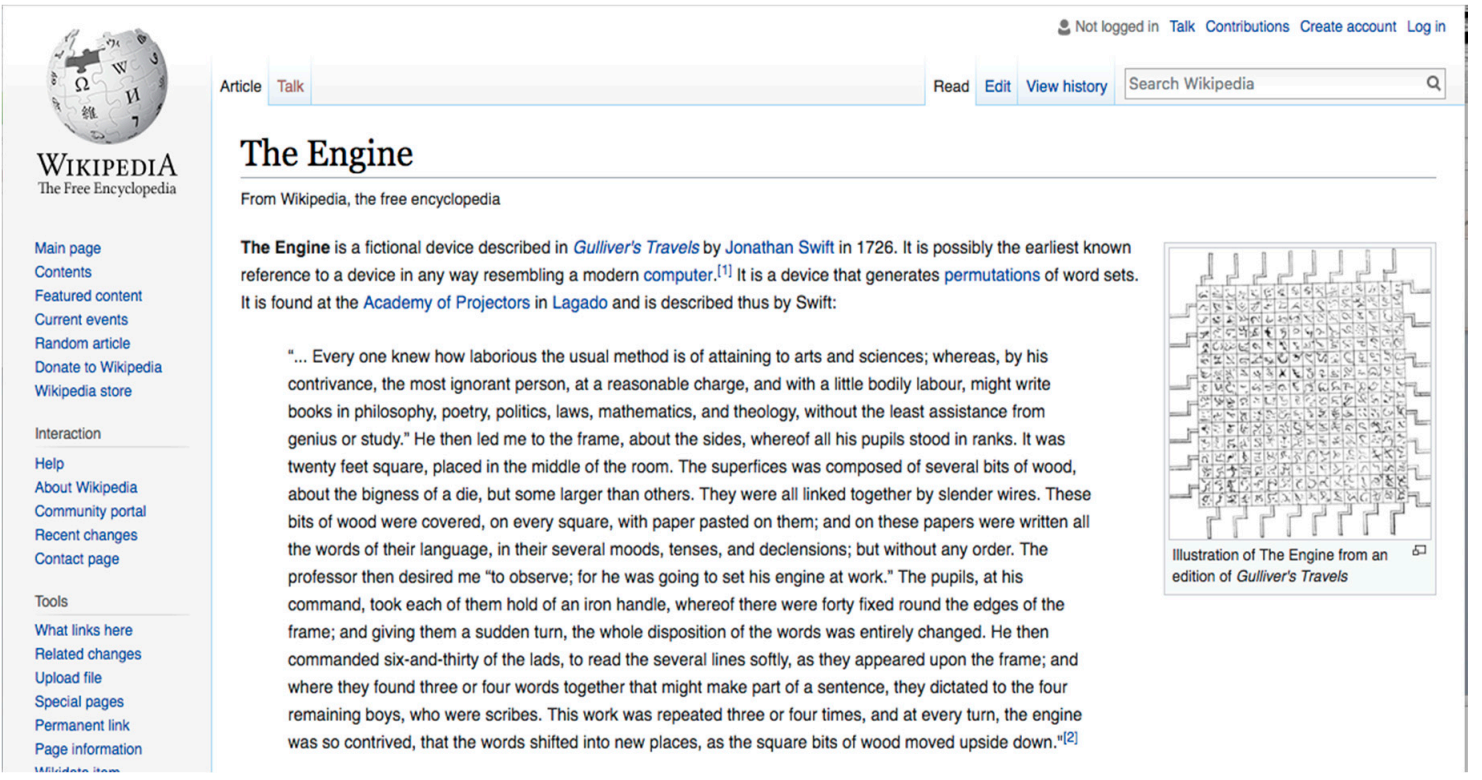

Figure 2. Screenshot of The Engine. Wikipedia: The Free Encyclopedia. San Francisco: Wikimedia Foundation, Inc. 12 May 2016.

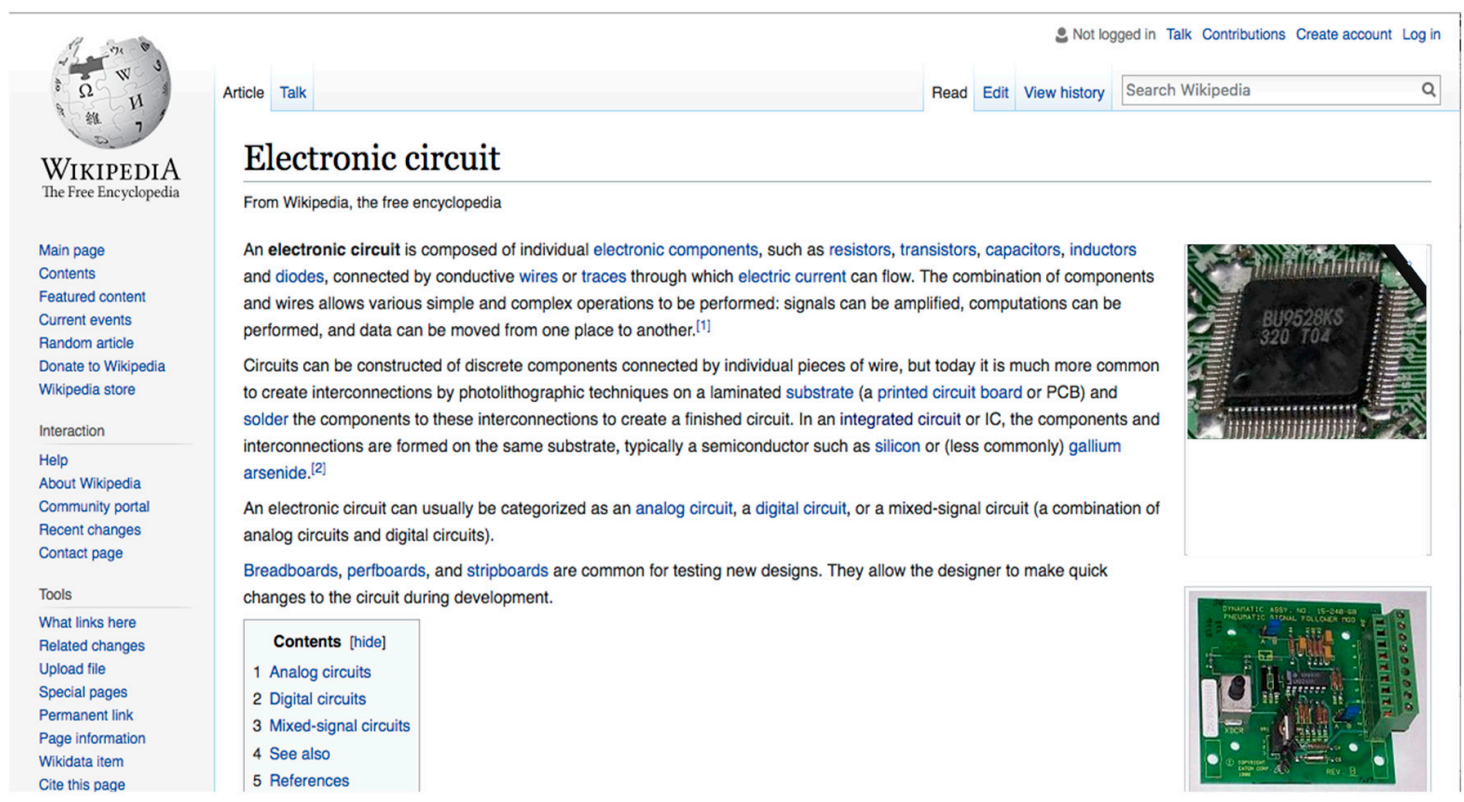

Figure 3. Screenshot of Electronic Circuit. Wikipedia: The Free Encyclopedia. San Francisco: Wikimedia Foundation, Inc. 12 May 2016. 


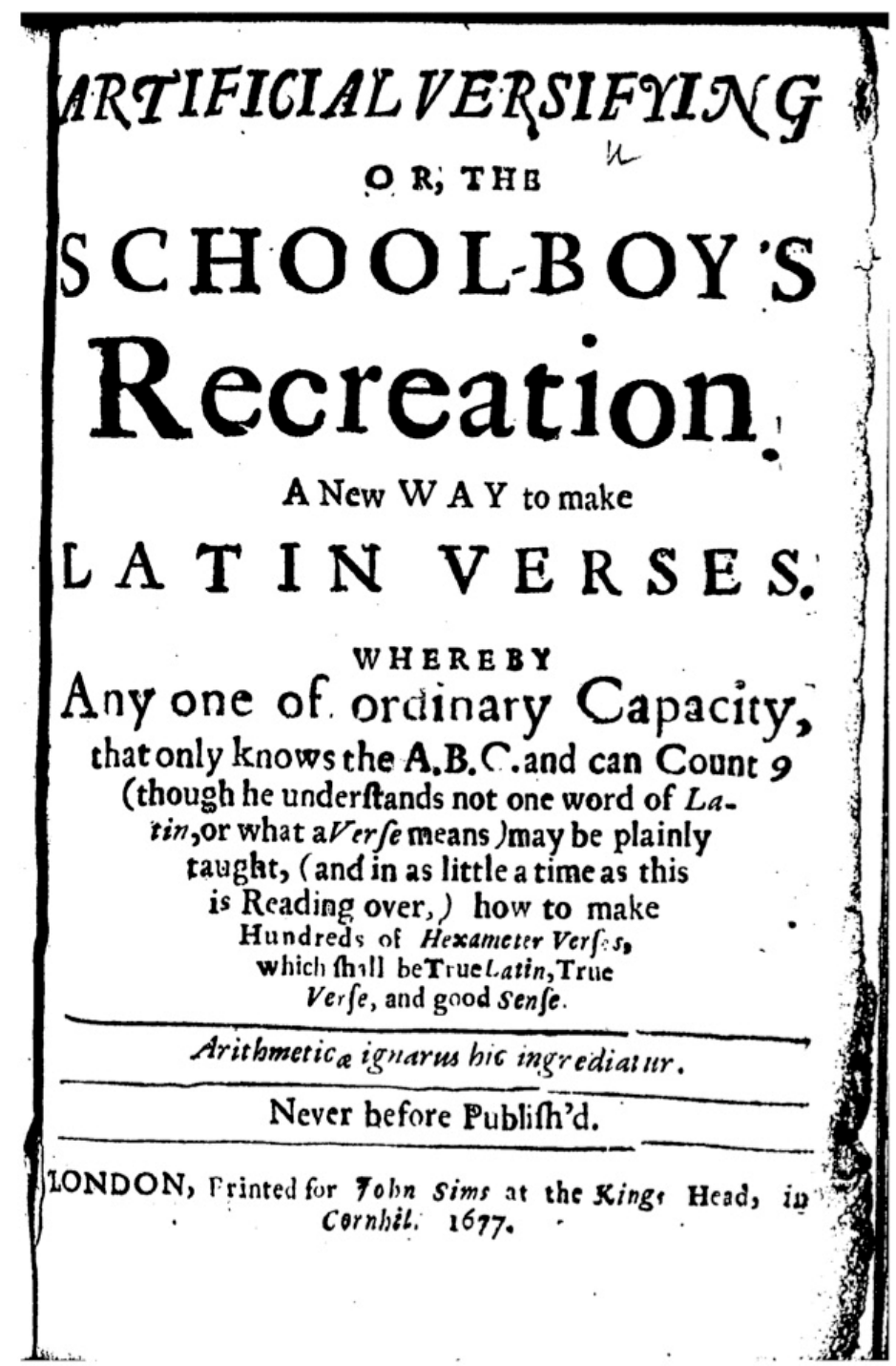

Figure 4. Title page from John Peter's Artificial Versifying (John Sims, 1677).

Made up of a brief introduction and detailed instructions for using its enclosed tables, each of which is comprised of a variable number of letters and blank spaces, Peter's pamphlet is itself a tool for the generation of lines of Latin hexameter verse (Figure 5). Advertised by Peter and his publisher John Sims as a publication that will allow anyone of the "meanest capacity" to assemble verses in Latin, the rules of Peter's game are as follows: To begin, readers are instructed to select "six of the nine figures called digits" from 1-9. Using the figures 4,6,7,1,8,2 as an example (Figure 6), Peter explains how these, when applied to the tables, will result in the verse line, "Tristia fata tibi producunt sidera prava", which he does not translate for the reader, but that can be translated as "sad fate will produce perverse stars", (Google Translate, 19 May 2016 3:55 p.m. EDT) or, alternately, as, "sad fate brings to light crooked stars" (Figure 7). 
Six Versifying Tables from

John Peter's Artificial Versifying (John Sims, 1677)

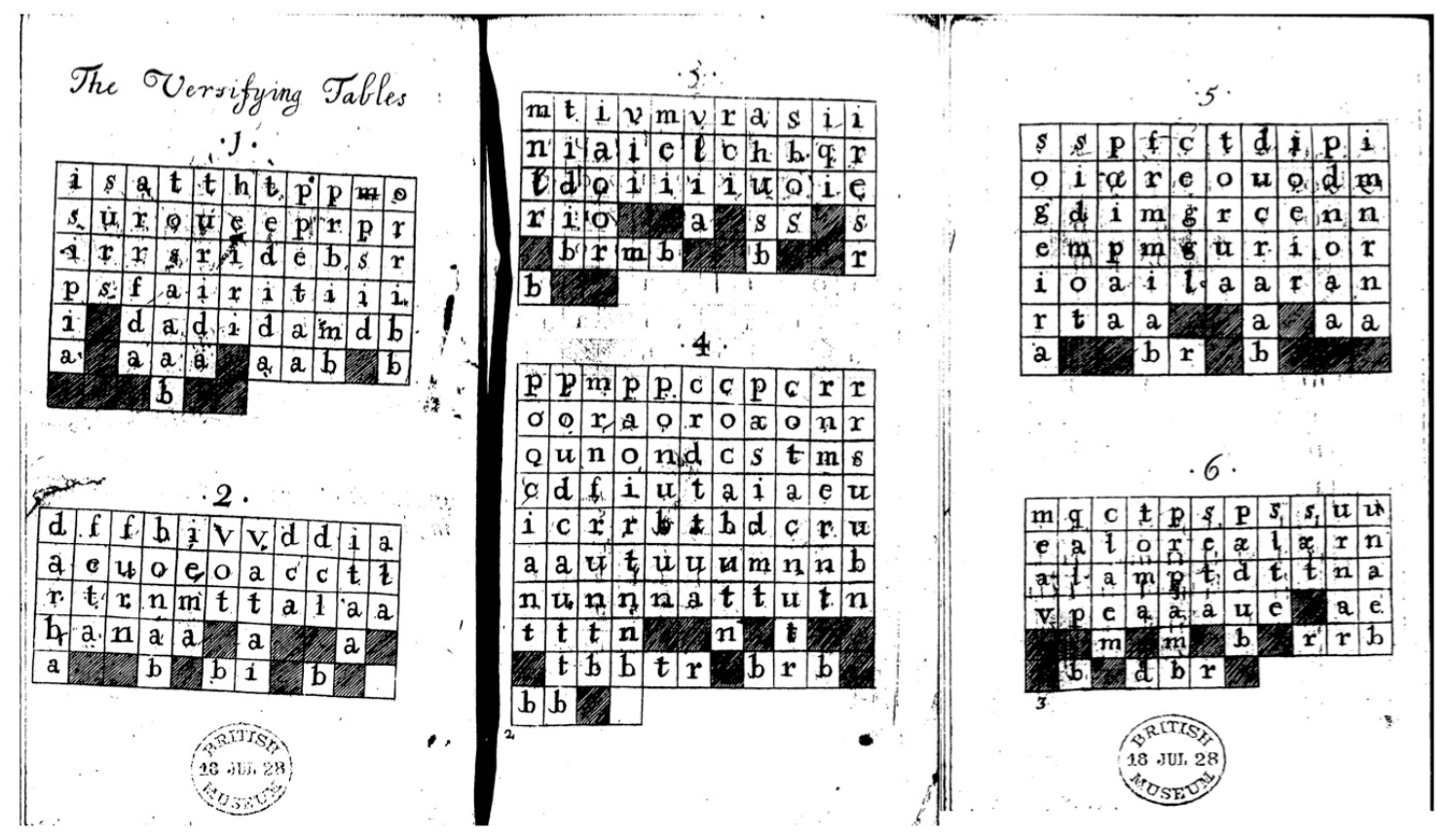

Figure 5. The Six Versifying Tables from John Peter's Artificial Versifying (John Sims, 1677).

Six Versifying Tables from John Peter's Artificial Versifying (1677)

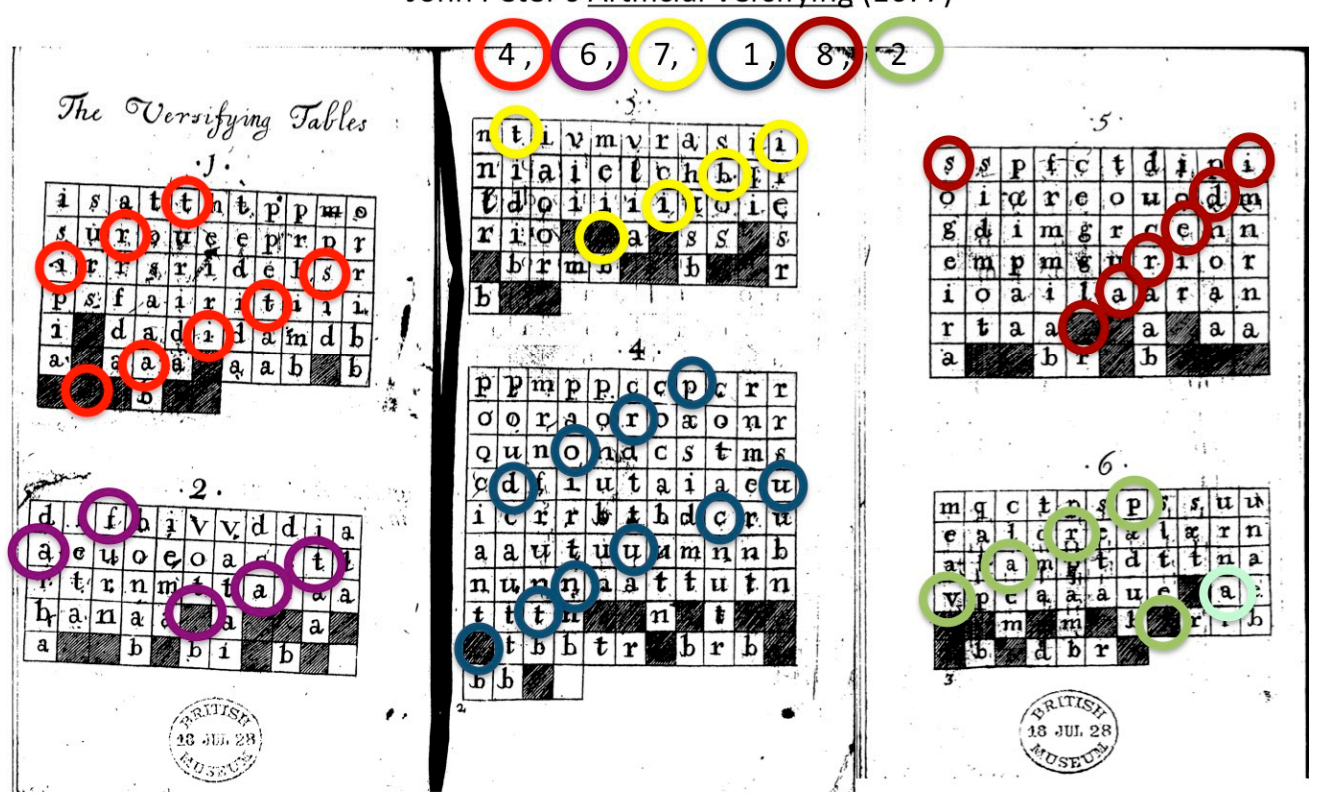

Figure 6. One example of John Peter's versifying tables in use. Applying the six digits 4, 6, 7, 1, 8, 2 to the six tables according to Peter's guidelines, a user can generate six Latin words that will form one line of hexameter verse (Artificial Versifying, John Sims, 1677). 


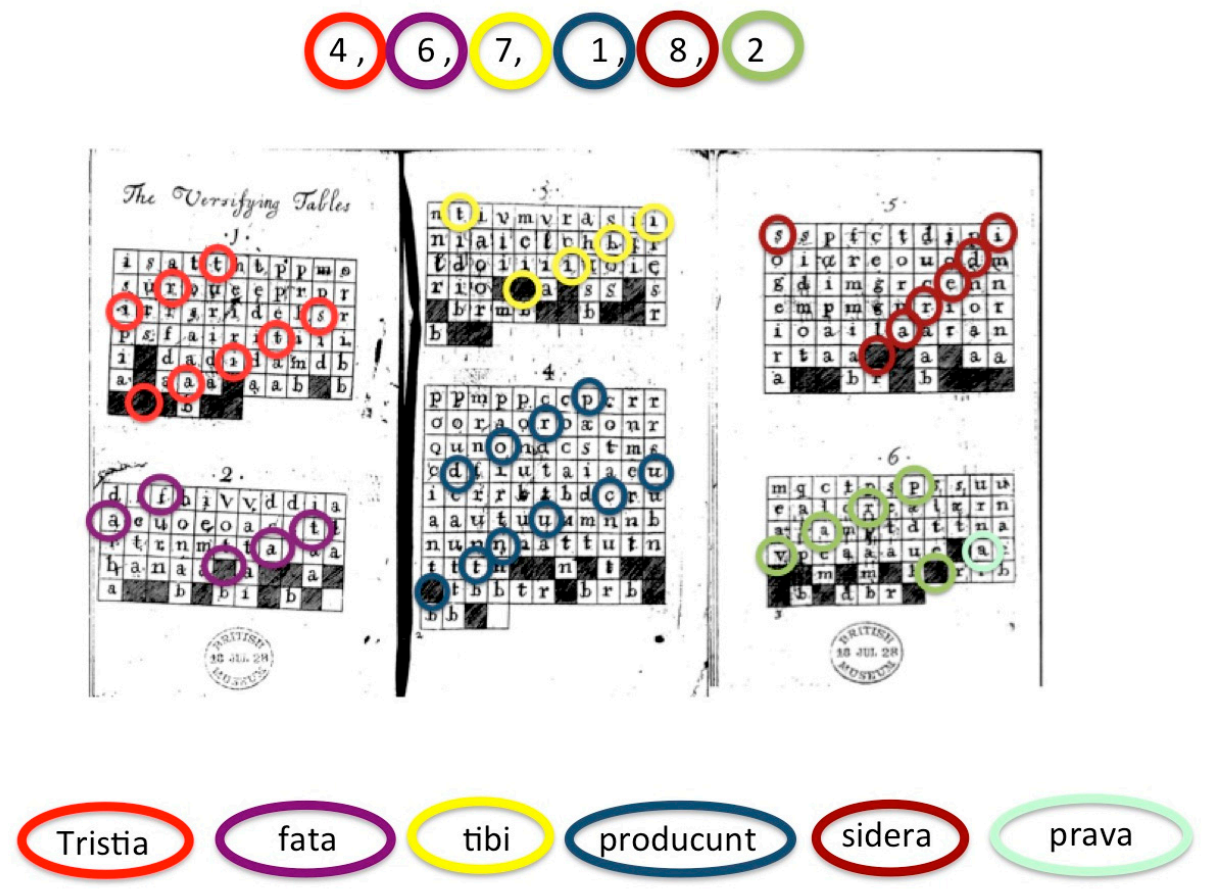

Figure 7. The resulting Latin verse line based on the application of the six digits 4, 6, 7, 1, 8, 2 (Artificial Versifying, John Sims, 1677).

Describing each one of the figures as "so many respective keyes to the six tables" in his introduction, Peter offers a further analogy between the musical performer and his instrument and between a "carpenter, glasier, or brick layer" and his rule to illustrate the numerous advantages that have resulted from the application of scientific knowledge via tools used even by those who do not understand the theories through which such tools operate. He then concludes his introduction by suggesting that "the Latinist and the poet" have heretofore internalized the set of compositional tools that Peter is now making available to even those who cannot read or write.

In proposing that verse composition is a kind of advanced calculation that some have mastered but that all could have access to via a tool, such as his, which, like other tools and instruments, allow those who are "altogether ignorant of arithmetick, and of all literature" to perform tasks reliant upon a knowledge of both, Peter is offering proof of how written messages can be made to function instrumentally, even by those who have no understanding of their significance or rationale. Thus, in suggesting that reading and writing practices may exist in some relation to computation and to the tools and technologies with which computational acts are materialized, shared, and distributed, Peter's tables are an early exploration of the potential performances enabled through the separation of a rhetorical act (the making of meaning) from the rhetorical context to which it is attached (the rationale for the making of meaning).

In terms of the reception of Peter's pamphlet, Richard Steele's (1726) reference to it in a 1711 Spectator article dedicated, ostensibly, to satirizing the invention is significant not only because its inclusion in the magazine suggests that Swift would have been aware of the pamphlet but also in light of the terms used to describe and interpret it. In the brief notice that forms part of the magazine's ongoing coverage of "projectors", or "mad" inventors, Steele describes Peter's project as a kind of "poetical logarithm", and in doing so connects it to the work of the 17th century Scottish mathematician John Napier (1614), who, with the publication of his 1614 Logarithmorum Canonis Descriptio, is the first to apply the term "logarithm" to the computational tables published in the book, and who is listed on the book's title page as both the author of the book and the inventor of its contents (Figure 8). The epigraph on the pamphlet's title page "Arithmeticae ignarum hic ingrediatur", "Let those ignorant of arithmetic enter here", a play on the (in)famous epigraph attributed to Pythagoras, "Nemo arithmeticae ignarum 
hic ingrediatur" (Let none ignorant of arithmetic enter here) connect it to the history of educational textbook publishing, as does the later use of its tables, which are reprinted and referred to as a pedagogic tool in 18th and 19th century math and language textbooks (Bailey 1721; Lowe 1749). The pamphlet's publicity, its later two editions, and its pedagogic applications may help to explain how it came to be used as the "software" for an actual writing machine, the Eureka, constructed by John Clark and exhibited in London in 1845 (Figure 9).

\section{John Napier's Mirifici Logarithmorum Canonis Descriptio, 1614}

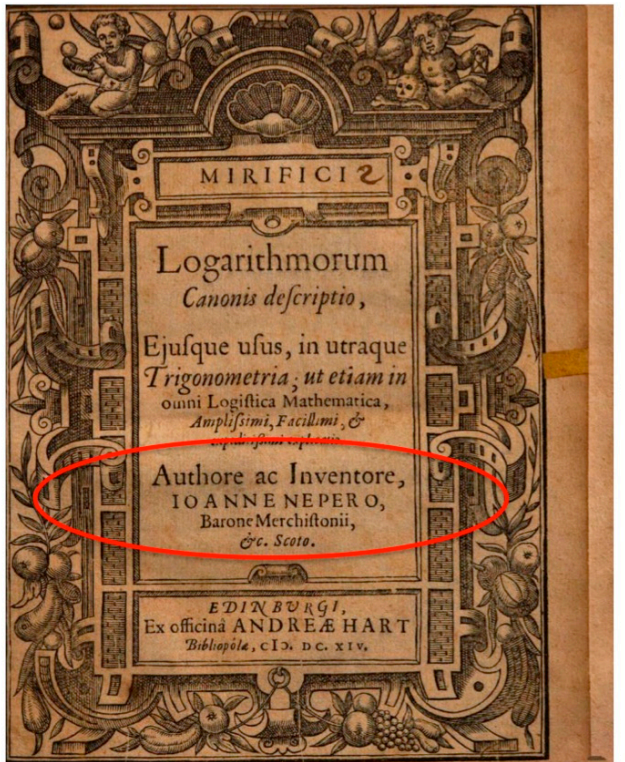

Figure 8. Title page from John Napier's Logarithmorum Canonis Descriptio (Andrea Hart, 1614).

John Clark's Latin Versifying Machine The Eureka (1845)
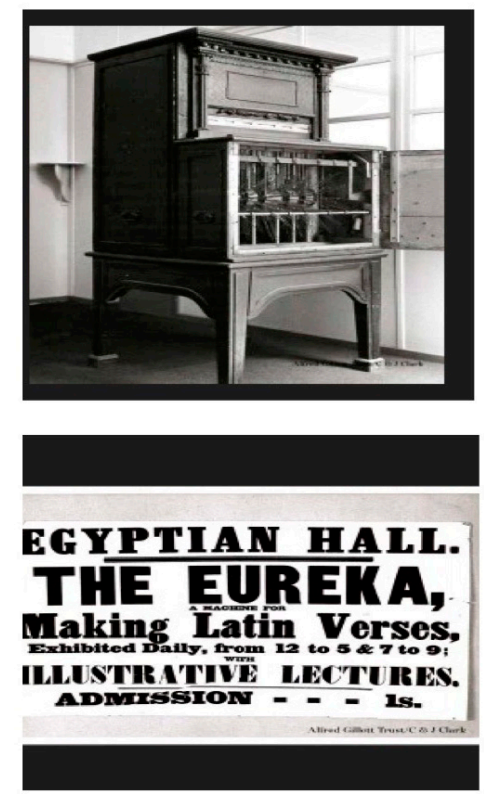

Figure 9. John Clark's Latin versifying machine, The Eureka (top) and an entry ticket (below) to the machine's exhibition at the Egyptian Hall, Piccadilly (Alfred Gillett Trust). 
While all print satire relies on the tensions existing between ideas and their material presentation, Swift's entire project in the work entitled Travels into Several Remote Nations by Lemuel Gulliver originated in part as a satire of "the book" as material and socio-economic phenomenon. A novel that is in its entirety "regulated by an inclusive fiction of the text" (Castle 1993, p. 59), Gulliver's Travels is also dedicated, particularly in the third part, to satirizing a number of scientific inventions and the roles of printers and the press in verifying and securing ownership of them (Nicolson and Mohler 1937a; Lund 1983; Lynall 2012; Smith 1990; Kiernan 1971; Ehrenpreis 1957, 1989). In fact, in the scene in which the details of the "wonderful machine" are recorded, Gulliver functions both as draughtsman and publisher promising to not only document the invention accurately but to secure the professor's ownership of it should he ever have the opportunity to share his graphic description with others. In this context, it is then all the more noteworthy that the contrivance that Swift created to satirize instrumentalist approaches to knowledge production is received as "knowledge engine" at least in part because of the publishing technologies and book trade practices of his time and ours (Bullard and McLaverty 2013; Karian 2014). For, as was the case with the other graphic elements, the author's frontispiece and four maps, also included in the early editions of the novel, it now appears that Swift's publisher, Benjamin Motte, played a significant role in overseeing their design and production. ${ }^{2}$ Fixed by a graphic image and functioning as a metonym for Swift's entire project in the third part of the novel, the "knowledge engine" reveals the unique tensions that have always existed amongst Swift's elaborate, original "code" that is the verbal text of the third part of Gulliver's Travels; the numerous scientific, cultural, and political sources being satirized; and the printing and publishing technologies that contributed to the production of the first edition of the material book and that continue to enable the text's remediation and distribution.

Conflicts of Interest: The author declares no conflict of interest.

\section{References}

Babbage, Charles. 1822. Letter to Sir Humphrey Davy. London: J. Booth.

Bailey, Nathan. 1721. An Universal Etymological Dictionary. London: Printed for E. Bell, etc.

Barchas, Janine. 2003. Graphic Design, Print Culture, and the Eighteenth Century Novel. Cambridge: Cambridge University Press.

Bracher, Frederick. 1944. The Maps in 'Gulliver's Travels.'. Huntington Library Quarterly 8: 59-74. [CrossRef]

Paddy Bullard, and J. McLaverty, eds. 2013. Jonathan Swift and the Eighteenth-century Book. Cambridge: Cambridge University Press.

Castle, Terry J. 1993. Why the Houyhnhnms Don't Write: Swift, Satire and the Fear of the Text. In Critical Essays on Jonathan Swift. Edited by Frank Palmeri. Boston: G. K. Hall.

Cornelius, Paul. 1965. Languages in Seventeenth and Early Eighteenth-Century Imaginary Voyages. Geneva: Librarie Droz.

Didicher, Nicole. 1997. Mapping the Distorted Worlds of Gulliver's Travels. Lumen: Selected Proceedings from the Canadian Society for Eighteenth-Century Studies/Lumen: Travaux Choisis de la Société Canadienne d'Étude du Dix-Huitième Siècle 16: 179-96. [CrossRef]

Ehrenpreis, Irvin. 1957. The Origin of Gulliver's Travels. PMLA. December, 72. Available online: http:/ / www. jstor.org/stable/460368 (accessed on 10 October 2017). [CrossRef]

Ehrenpreis, Irvin. 1989. The Allegory of Gulliver's Travels. Swift Studies 4: 13-28.

2 That Swift and his friends-Pope, Ford, Gay, and Arbuthnot—engaged in various acts of satirical forgery is well known, making it seem all the more likely that they may have been involved in the creation of the fictional maps modeled to resemble those of the famous map maker Herman Moll or the inclusion of a portrait of a fictional character as authorial frontispiece (Bracher 1944; Didicher 1997). However, whether or not Swift was involved with the design and production of the four maps and one "diagram" included in the first edition of the book is still, despite almost a century of scholarly attention, an issue yet to be resolved through documentary evidence (Williams 1925; Hubbard 1922; Halsbland 1985; Sena 1990). What we do know from Swift's correspondence is that he was consulted by his publisher regarding the illustrations for the 1747 edition and that he authorized the inclusion of the maps and diagram in the 1735 Faulkner edition (Barchas 2003; Swift 1912a, 1912b, 1912c, 1912d). 
Halsbland, Robert. 1985. Eighteenth Century Illustrations of Gulliver's Travels. In Proceedings of the First Münster Symposium on Jonathan Swift. Edited by Hermann Josef Real and Heinz J. Vienken. München: W. Fink.

Hubbard, Lucius Lee. 1922. Contributions towards a Bibliography of Gulliver's Travels. Chicago: Walter M. Hill.

Karian, Stephen. 2014. Jonathan Swift in Print and Manuscript. Cambridge: Cambridge University Press.

Kiernan, Colin. 1971. Swift and Science. The Historical Journal 14: 709-22. [CrossRef]

Knowlson, James. 1975. Universal Language Schemes in England and France 1600-1800. Toronto: University of Toronto Press.

Koch, Lawrence Andrew. 1996. Silicon Poetics: The Computer as Artifice and Author. Master's thesis, University of Montana, Missoula, MT, USA.

Liu, Lydia H. 2011. The Invention of Printed English. In The Freudian Robot: Digital Media and the Future of the Unconscious. Chicago: The University of Chicago Press.

Lowe, Solomon. 1749. Arithmetic in Two Parts. London: James Hodges.

Lund, Roger D. 1983. Res et Verba: Scriblerian Satire and the Fate of Language. The Bucknell Review 27: 63-80.

Lynall, Gregory. 2012. Swift and Science: The Satire, Politics, and Theology of Natural Knowledge, 1690-1730. New York: Palgrave Macmillan.

Napier, John. 1614. Logarithmorum Canonis Descriptio. Edinburgh: Andrea Hart.

Nicolson, Marjorie, and Nora M. Mohler. 1937a. The Scientific Background in Swift's Voyage to Laputa. Annals of Science 2: 299-334. [CrossRef]

Peirce, C. S. 1887. Logical Machines. The American Journal of Psychology 1: 165-70.

Peter, John. 1677. Artificial Versifying, or the Schoolboy's Recreation. London: John Sims.

Porter, David. 1993. Ideographia: The Chinese Cipher in Early Modern Europe. Stanford: Stanford University Press.

Walter Scott, ed. 1814. The Works of Jonathan Swift. Westminister: Archibald Constable.

Sena, John F. 1990. Gulliver's Travels and the Illustrated Book. In The Genres of Gulliver's Travels. Edited by Frederik N. Smith. Newark: University of Delaware.

Smith, Frederik N. 1990. Scientific Discourse: Gulliver's Travels and The Philosophical Transactions. In The Genres of Gulliver's Travels. Edited by Frederik N. Smith. Newark: University of Delaware.

Steele, Richard. 1726. November 13, 1711. The Spectator 3: 287.

Swift, Jonathan. 1726. Travels into Several Remote Nations of the World. [writing as Lemuel Gulliver]; London: Benjamin Motte.

Swift, Jonathan. 1912a. Swift to Benjamin Motte, December 28, 1727. Correspondence 3: 438-39.

Swift, Jonathan. 1912b. Swift to Alexander Pope and John Gay, October 15, 1726. Correspondence 3: 347-48.

Swift, Jonathan. 1912c. John Arbuthnot to Swift, November 8, 1726. Correspondence 3: 350-51.

Swift, Jonathan. 1912d. John Gay and Alexander Pope to Swift, November 17, 1726. Correspondence 3: 358-59.

Swift, Jonathan. 1978. Gulliver's Travels. Edited by Peter Dixon and John Chalker. London: Penguin.

Weiss, Eric A. 1985. Jonathan Swift's Computing Invention. IEEE Annals of the History of Computing 7: 164-65. [CrossRef]

Williams, Harold. 1925. The Motte Editions of Gulliver's Travels. The Library 6, December. OUP. Available online: http:/ / library.oxfordjournals.org/content/s4-VI/3/229.full.pdf+html (accessed on 3 March 2016).

(C) 2017 by the author. Licensee MDPI, Basel, Switzerland. This article is an open access article distributed under the terms and conditions of the Creative Commons Attribution (CC BY) license (http:/ / creativecommons.org/licenses/by/4.0/). 